\title{
I Didn’t Want to Be a Jew (Nechcel som byt' žid)
}

Author: Juraj Špitzer

First Published: 1994

Translation: Hungarian (Nem akartam zsidó lenni, 2007).

About the Author: Juraj Špitzer (1919-1995) was a Slovak writer, novelist, essayist, literary scientist and critic, screenwriter, journalist and publicist. He studied medicine in Prague, but after the Nazi occupation of the Czech lands he was expelled from his studies due to his Jewish origins and he returned to Slovakia. From 1942 he was held for two years in an internment labour camp for Slovak Jews in the town of Nováky where he met the writer Leopold Lahola under dramatic circumstances. He participated in the resistance against the Slovak fascists and Nazis. He was commander of the Jewish partisan unit. This experience later inspired him to write the screenplay for the film White Clouds (directed by Ladislav Helge, 1962), which he reworked into a short story. After the war, he studied French and philosophy at Comenius University in Bratislava. From 1949 he was one of the more important members of the Communist Party and worked in the cultural department of the Central Committee of the Communist Party of Slovakia, and then in the Institute of Slovak Literature of the Academy of Sciences. In 1951 he gave a sharply critical report to the members of the avant-garde prewar Slovak DAV writers group, accusing them of "bourgeois nationalism". He later apologised for this. From 1956 to 1958 and then from 1965 to 1967 he was editor-in-chief of Kultúrny život, a major contributor to the liberalisation of culture, and in 1967 Secretary of the Union of Czechoslovak Writers. Due to his support for the liberal reforms during the Prague Spring in 1968 and 1969, he lost his cultural and political positions and was not allowed to publish until 1989.

Špitzer's novel I Belong to You was one of the first books in Czechoslovakia to discuss the consequences of the political trials in the 1950s. The novella reminds readers of the real events, the accusation and the trial of the author's fellow combatant, who vainly sought rehabilitation and committed suicide. Špitzer published most of his essays, reflections and prose only after 1989. He deals with Jewish themes and antisemitism in the collection of reflections Dawn Comes when the Darkness Is Complete. Weekdays was published posthumously from Špitzer's estate. These are reminiscences, reflections on the history of Slovakia, "historically-informed" comments and observations. They are, as said by the author, a personal history of thought and emotional education, which can also be called home.

Further Important Publications: Biele oblaky (1963, White Clouds; novella); Patrím k vám (1964, I Belong To You; novella); Letná nedela (1991, A Summer Sunday; novella);

Ә Open Access. () 2021 Zora Prušková, published by De Gruyter. (cc) BY-NC-ND This work is licensed under a Creative Commons Attribution-NonCommercial-NoDerivatives 4.0 License. https://doi.org/10.1515/9783110671056-051 
Svitá, až ked'je celkom tma (1996, Dawn Comes when the Darkness Is Complete; reflections); V̌̌edné dni (2001, Weekdays; memoirs and reflections).

\section{Content and Interpretation}

Prose with autobiographical features describes the author's stay in an internment work camp for Slovak Jews in the town of Nováky. Juraj Špitzer, as a Jewish witness to the persecution of Jews and the Holocaust in Slovakia, approaches these events from two sides and two sources. One is to evoke specific situations, characters and events. This is done through narration in the form of memories of a young man, a boy who is trying to survive in difficult circumstances, after the outbreak of the persecution of the Jews in Slovakia. His arrival at the internment work camp in Nováky is the exposition of the novel. Another narrative contains fragments-scenes of experiences from the camp until the moment when the rebellion was being prepared. The author strives for an objective style. He recalls facts, often presents figures and dates, and reproduces details from administrative reports, reports, circulars, resolutions, decisions and statistics. He writes about the Slovak variant of the solution of the Jewish question between 1939-1945. He speaks from his own experience. It is personal experience that gives the narration vivid colour. It is revived by memory and probably also supplemented by the author's historical records of the most important events. The other component of the narrative is an ironic-sceptical attitude towards great historical changes. Small people are in the shadow of this great history, and their responsibility for the immoral or underpowered is not the same for everyone. Human "nature", inclinations to good or evil, is random in Špitzer's concept. However, the story of Jewish destiny is fatally determined. This clash of the objective truth about man and the subjective melancholy of the witness is also evident in the narrative style. It manifests itself in distance, irony and, in places, in an almost self-healing humour. As he recalls, he never understood why the state sent its loyal citizens, the Jews, to the death. It is not a monologue when this reflection is evaluated by the participant. It is more of a conversation, a controversy with everything that troubled him humanly and intellectually. Although the Holocaust is a major theme in Špitzer's books, it is always accompanied by ramified, branched reflections on its context, a context with what is deeply in human nature. That is why this narrative, semantically open, is constructed as the author's conversation with himself. It is a sceptical paraphrase of Psalms, because God is no longer apostrophised. The author addresses the reader, appeals to his sensitivity and perceptiveness. He has a repeated need to return to the Holocaust as an unfinished event. Quotes from the ancient Jewish philosopher, writer and historian Flavius Josephus appear in the novel I Didn't Want to Be a Jew. It is always at the interface of chapters into which prose is divided. Quotes are selected from his military biography as well as from the writings of The Jewish War and Antiquities of the Jews.

Špitzer's disposition was intellectually restless and sceptical. If he had a foothold in authority, its experience and opinions, it was Josephus's writings, read by the author responsibly and empathically. There are six quotations from Flavius Josephus 
in the prose. Upon arriving at the camp in Nováky, a quote from The Jewish War appears: "We were born for death, and for our offspring were born, and even those who live in bliss cannot escape it.” (Špitzer, 1994, p. 67)

Špitzer also writes, following a formulated, presented picture of Jewish destiny: "I would like to throw away from memory all the evil things that resemble those years. I would never want to see people again as they were then, neither as prisoners nor as jailers. At times, it seems to me that my experience in Nováky has been covered by oblivion. But the incomprehensible and distant context - a facial expression, raised voice, modulation and colour, gesture, movement or footsteps - suddenly the experience in Nováky returns as a severe pain.” (pp. 291-292)

\section{Main Topics and Problems}

"Answering antisemitism is not a matter of Jews, but of non-Jews." (Špitzer, 1996, p. 204) This statement, referring to Sigmund Freud, can be found in Špitzer's essayist book Dawn Comes when the Darkness Is Complete. It is an autobiography based text, as well as the novel I Didn't Want To Be a Jew. Here, Špitzer brings a sad testimony to the fate of the Jews, not only in the historical framework of the 20th century. It tries to summarise the facts of the displacement of the Jews beyond their homeland and to understand them in concrete contexts. It tries to understand the persecution and marginalisation of this ethnic group, which culminated in mass destruction in the mid-20th century. He also talks about the Holocaust as well as the identity of the Jews, their sense of belonging to the state, the country and their homeland, which renounces their citizens. The Holocaust literature brings the experience that it is impossible to give accurate testimony when writing about traumatic events. With the passage of time, stereotypes that bring newspeaks full of clichés are gaining ground. The traumatic core of events remains deeply hidden in memory. In the current Holocaust literature, the term traumatic realism (Michael Rothberg) appears in this context, trying to name the language and imagery responsibly representing the traumatic memory (mainly in the works of Ruth Klüger and Charlotte Delbo). Rothberg deals with the description and specificity of this depiction, which is in contrast to the current dominant narrative. The traumatic event either depicts the means of literary clichés or marginalises them. In his book, Špitzer chooses the middle way. He places facts (names, dates, locations, events) that are proven and evoked by memory in a linear narrative. The author thus provides the readers with "live images", composed scenes that he completes with distance and reflection. This is manifested mainly in the composition procedures (devices) and the text structure.

\section{Cited Works}

Špitzer, J. (1994). Nechcel som byť žid. Bratislava: Kalligram. Špitzer, J. (1996). Svitá, až ked'je celkom tma. Bratislava: Kalligram. Špitzer, J. (2001). Všedné dni. Bratislava: Vydavatel'stvo Ivan Štefánik. 


\section{Further References}

Drug, Š. (2001). Nevšedný život a dielo Juraja Špitzera. In: J. Špitzer, Všedné dni. Bratislava: Vydavatel'stvo Ivan Štefánik, pp. 9-23. Kamenec, I. (1997). O kolobehu tmy a svitania v (našich) dejinách: Juraj Špitzer: Svitá, až ked' je celkom tma. Romboid, 32 (1), pp. 71-73. Klíma, I. (1994). Kniha nejen o židovském údělu. Mosty, 3(35), p. 13. Prušková, Z. (2016). Ako si porozumiet's literatúrou. Bratislava: Literárne informačné centrum, pp. 126-128.

ZP 